\title{
Potassium Supplying Capacity of Representative Soil Series of Sub-Montane Zone of Maharashtra, India
}

\author{
M.V.V.I. Annapurna*, B.S. Kadam, Nilam B. Kondvilkar and H.K. Surabhi
}

Department of Soil Science and Agricultural Chemistry, College of Agriculture, Kolhapur, Mahatma Phule Krishi Vidyapeeth, Rahuri, Maharashtra, 413 722, India

*Corresponding author

\section{A B S T R A C T}

Neubauer seedling experiment was carried out for determining the potassium supplying capacity of different representative soil series of order Entisols, Inceptisols and Vertisols

Keywords

Potassium supplying capacity,

Neubauer number,

Wheat.

Article Info

Accepted:

17 October 2017

Available Online:

10 December 2017 collected from agriculture college Kolhapur and different research stations of Sub-montane zone of Maharashtra. In this experiment, 50 seedlings of wheat were made to feed exhaustively on 100 grams of soil mixed with 100 grams of quartz sand for 17 days in plastic dishes. The total $\mathrm{K}$ uptake by wheat seedlings from different soil series was calculated from which the control value was deducted to obtain the "root-soluble" $\mathrm{K}$ in soil. These values are designated as the Neubauer numbers, expressed as mg per $100 \mathrm{~g}$ of air-dry soil. The Neubauer limit value for wheat is $20 \mathrm{mg} \mathrm{K}$ per $100 \mathrm{~g}$ of dry soil and the soils which are having less value than the above is being considered to have poor potassium supplying capacity. Among the different soil series, the highest potassium supplying capacity was observed in Koregaon series (Vertisol) of A.R.S., Karad with neubauer number 38 and the lowest potassium supplying capacity was noticed in Sathesai series (Entisol) of N.A.R.P., Shendapark with neubauer number 7.90. The highest potassium supplying capacity was noticed in Vertisols followed by Inceptisols and Entisols.

\section{Introduction}

Potassium is an essential plant nutrient and plays several roles in plants such as enzyme activation, protein synthesis, ion absorption and transport, photosynthesis and respiration. Among the major plant nutrients in soil, potassium is the most abundant nutrient. Its amount in soils varies depending on parent material, degree of weathering, gains through fertilizers and losses through crop removal, erosion and leaching. Total potassium content in soils ranges between $0.5-2.5 \%$ with lower values in coarse-textured soils formed from sandstones or quartzite and higher contents in soils developed from parent material rich in $\mathrm{K}$ bearing minerals (Havlin et al., 2005).

Potassium releasing and supplying power of the soil are often used as synonyms. The knowledge of the rate of potassium release from soil might play an important role for comparing capacities of soil to supply potassium to plants (Srinivasrao et al., 2001). The actual K uptake by plants denotes the K supplying power of soil (Ramanathan and Krishmamoorthy, 1982). The ease with which the $\mathrm{K}$ released from non-exchangeable source 
without $\mathrm{K}$ application is an index on $\mathrm{K}$ supplying power. Therefore, precise prediction of $\mathrm{K}$ supplying power of soil both exchangeable and non-exchangeable forms of $\mathrm{K}$ needs consideration for better $\mathrm{K}$ management. The quantity of $\mathrm{K}$ consumed by high yielding varieties equals or in many times exceeds that of nitrogen and phosphorus and this aspect has become important in the context of modern intensive agriculture when growers aim at higher yields of crops per unit area and per unit time.

The information on potassium supplying capacity of representative soil series of Submontane zone of Maharashtra was limited, therefore the present investigation was planned.

\section{Materials and Methods}

\section{Neubauer technique}

In this technique, 50 seedlings of wheat were made to feed exhaustively on $100 \mathrm{~g}$ soil mixed with $100 \mathrm{~g}$ sand for 17 days in plastic dishes of $11 \mathrm{~cm}$ diameter and $7 \mathrm{~cm}$ depth. A control without any soil (only $100 \mathrm{~g}$ sand) is also taken. The total $\mathrm{K}$ uptake by wheat seedlings from soil series was calculated from wh88ich the control value was deducted to obtain the "root-soluble" $\mathrm{K}$ in soil.

These values are designated as the Neubauer numbers, expressed as mg per $100 \mathrm{~g}$ of air-dry soil. The Neubauer limit value for wheat is 20 $\mathrm{mg} \mathrm{K}$ per $100 \mathrm{~g}$ of dry soil and the soils which are having less value than the above is being considered to have poor potassium supplying capacity.

\section{Results and Discussion}

The data on production of dry matter yield, concentration and uptake of potassium by wheat crop in different soil series of Entisols,
Inceptisols and Vertisols are presented in the Table 1 and also depicted in Figure 1 and 2.

The significantly highest dry matter production $\left(\mathrm{g} \mathrm{pot}^{-1}\right)$ of the wheat was recorded in all the series over control. The Koregaon series of A.R.S., Karad (2.00 $\left.\mathrm{g} \mathrm{pot}^{-1}\right)$ of order Vertisol recorded significantly highest dry matter over all the other series except Koregaon series of A.R.S., Gadhinglaj from Vertisol. However, the differences among them were not significant.

The control treatment $\left(0.94 \mathrm{~g} \mathrm{pot}^{-1}\right)$ recorded significantly lowest dry matter production followed by Sathesai series of N.A.R.P., Shendapark (1.17 $\left.\mathrm{g} \mathrm{pot}^{-1}\right)$ of order Entisol. The similar results were also reported by Raskar and Pharande (1997).

The total potassium concentration in wheat was significantly highest in all the series over the control treatment.

The total potassium concentration was highest in Koregaon series of A.R.S., Karad (2.48 per cent) of order Vertisol and lowest in Sathesai series of N.A.R.P. Shendapark (1.70 per cent) of order Entisol.

The uptake of total potassium was found to be significantly highest in all the series over the control. The uptake of total potassium was high in Koregaon series of A.R.S., Karad (49.95 mg pot $\left.{ }^{-1}\right)$ of order Vertisol and low in Sathesai series of N.A.R.P. Shendapark $\left(19.85 \mathrm{mg} \mathrm{pot}^{-1}\right)$ of order Entisol. The results showed that the soil rich in available $\mathrm{K}$ are higher in K supplying capacity.

Low K supplying capacity was observed in Sathesai series (Entisols) at N.A.R.P., Shendapark with neubauer number 7.90 and high $\mathrm{K}$ supplying capacity observed in Koregaon series (Vertisol) at A.R.S., Karad with neubauer number 38 . 
Table.1 Potassium supplying capacity of surface soil in some representative soil series of Sub-montane zone of Maharashtra

\begin{tabular}{|c|c|c|c|c|c|c|c|}
\hline $\begin{array}{l}\text { Sr. } \\
\text { No. }\end{array}$ & $\begin{array}{l}\text { Soil } \\
\text { order }\end{array}$ & Location & Series & $\begin{array}{c}\text { Dry matter } \\
\left(\text { g pot }^{-1}\right)\end{array}$ & $\begin{array}{c}\text { Total K } \\
(\%)\end{array}$ & $\begin{array}{l}\text { K Uptake } \\
\left(\text { mg pot }^{-1}\right)\end{array}$ & Neubauer number \\
\hline 1 & & & Control & 0.94 & 1.27 & 11.95 & - \\
\hline 2 & Entisol & A.R.S., Karad & Ahmedpur & 1.55 & 1.86 & 28.88 & 16.93 \\
\hline 3 & & R.S and J.R.S., Kolhapur & Kurkum & 1.49 & 1.82 & 27.18 & 15.23 \\
\hline 4 & & N.A.R.P. (S.Z.) Kolhapur & Sathesai & 1.17 & 1.70 & 19.85 & 7.90 \\
\hline 5 & & A.C. farm Kolhapur & Kurkum & 1.38 & 1.79 & 24.81 & 12.86 \\
\hline 6 & & A.R.S., Vadgaon & Kurkum & 1.22 & 1.74 & 21.33 & 9.38 \\
\hline 7 & Inceptisol & A.R.S., Radhanagari & Kankauli & 1.57 & 1.98 & 31.21 & 19.26 \\
\hline 8 & & A.C. farm, Kolhapur & Bamburdi & 1.71 & 2.20 & 37.74 & 25.79 \\
\hline 9 & & A.R.S., Vadgaon & Bamburdi & 1.61 & 2.25 & 36.17 & 24.22 \\
\hline 10 & Vertisol & A.R.S., Karad & Koregaon & 2.00 & 2.48 & 49.95 & 38.00 \\
\hline 11 & & R.S and J.R.S., Kolhapur & Shiware & 1.86 & 2.35 & 43.57 & 31.62 \\
\hline 12 & & A.R.S., Gadhinglaj & Koregaon & 1.89 & 2.40 & 45.38 & 33.43 \\
\hline \multirow[t]{4}{*}{13} & & A.C. farm, Kolhapur & Donoli & 1.59 & 2.18 & 34.79 & 22.84 \\
\hline & & & Mean & 1.54 & 2.00 & 31.75 & \\
\hline & & & S.E. \pm & 0.05 & 0.06 & 1.79 & \\
\hline & & & C.D. at $5 \%$ & 0.13 & 0.17 & 5.19 & \\
\hline
\end{tabular}


Fig.1 Neubauer technique experiment

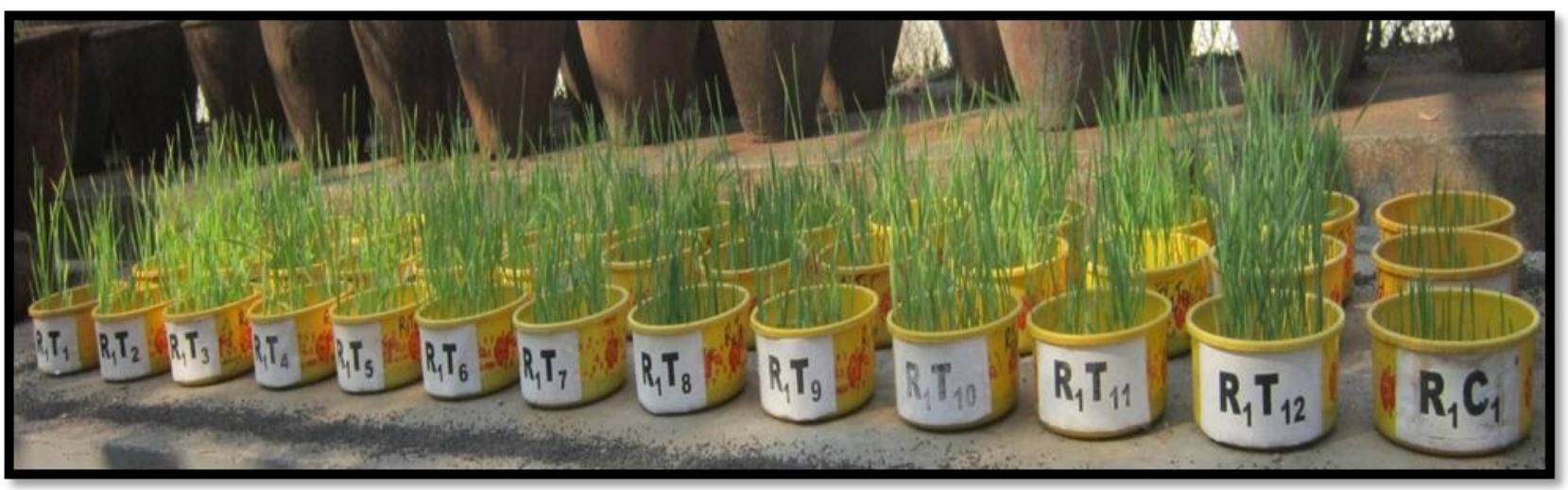

Fig.2 Comparison of control with different soil series

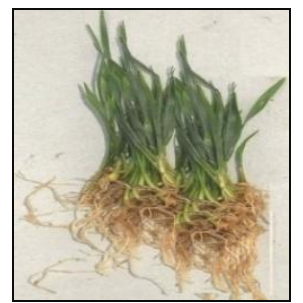

Control

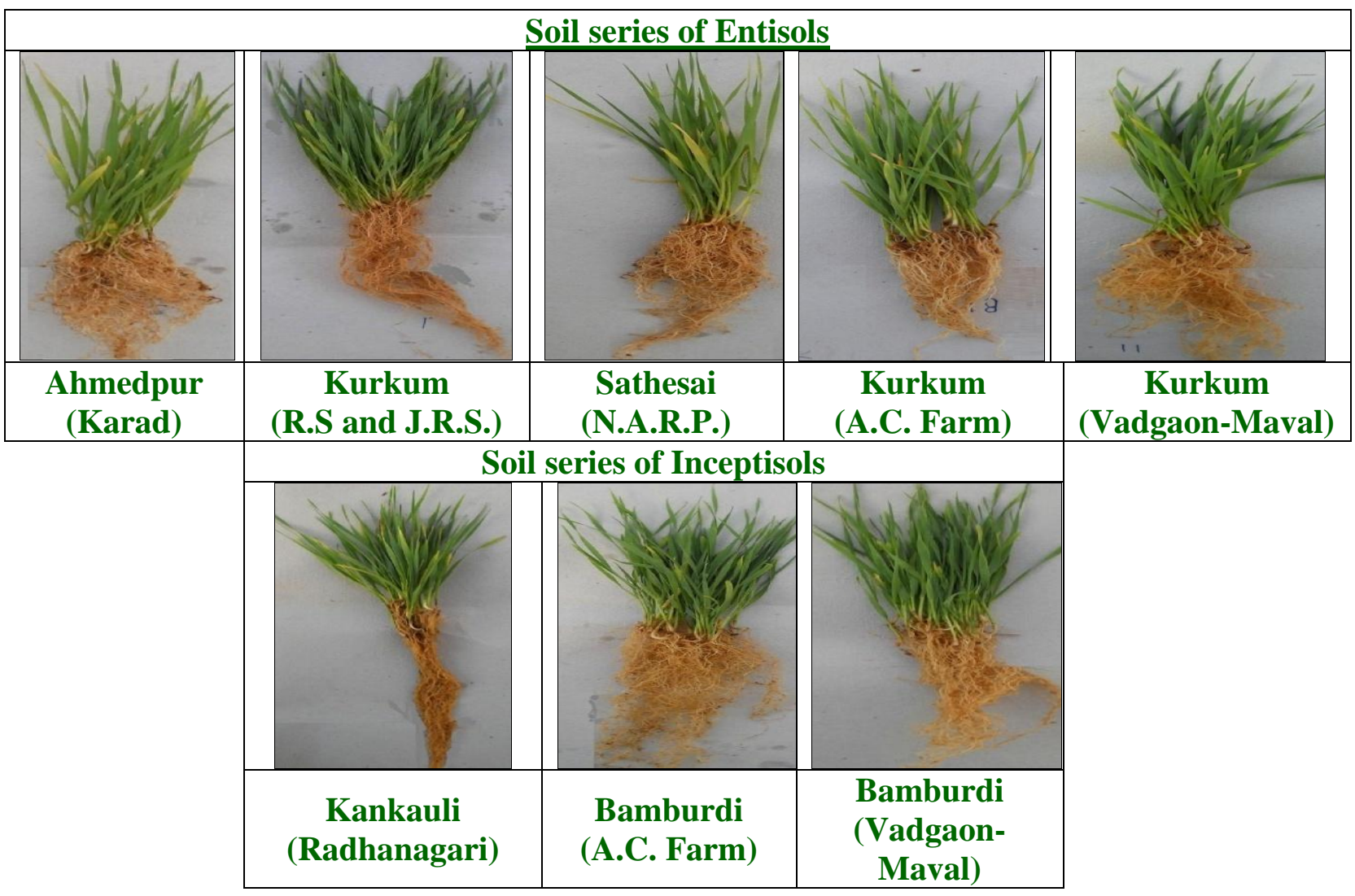




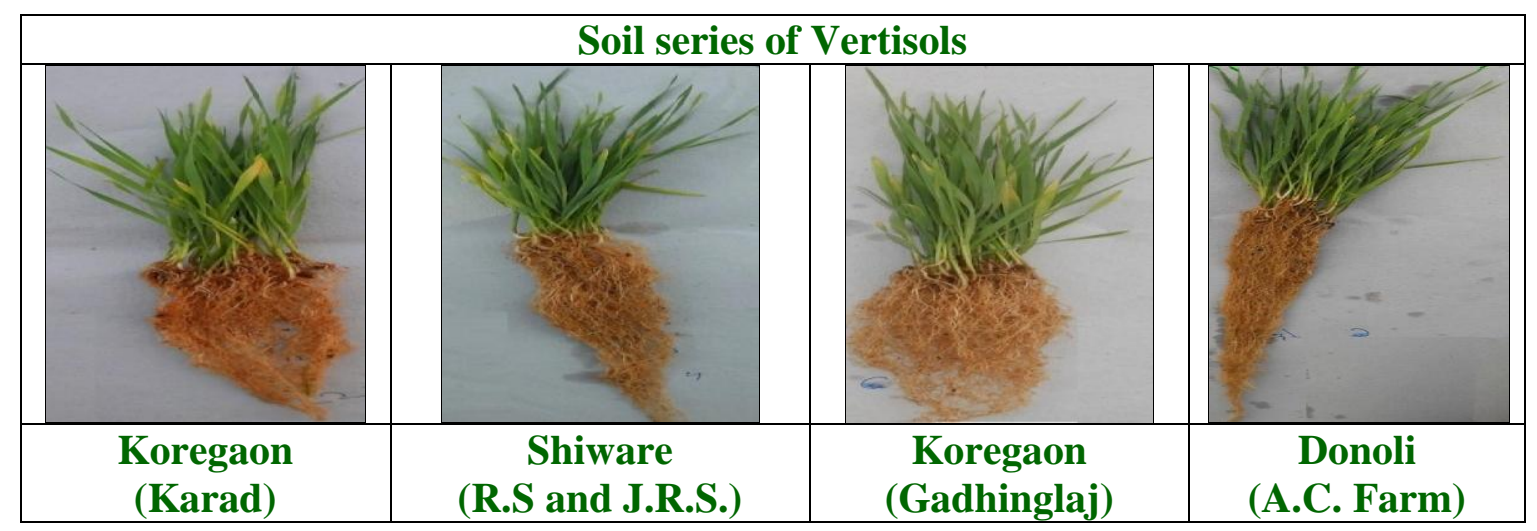

Potassium supplying capacity was highest in Vertisols followed by Inceptisols and Entisols. Similar results were reported by Pharande et al., (2007).

From the present investigation it could be concluded that the soil series of Sathesai, Kurkum, Ahmedpur and Kankauli were categorized as low in potassium content and can be corrected by intensive $\mathrm{K}$ fertilizer management for increasing crop production.

\section{References}

Havlin, J. L., Beaton, J. D., Tisdale, S. L. and Nelson, W. L. 2005. Soil Fertility and Fertilizers- an introduction to nutrient management. 17th Edward Pearson Education Inc., New Jersey, pp. 199218.

Pharande, A.L., Sumanta Kundu, Gajabhiye, P.N., Ch Srinivasarao, Vittal, K.P.R., Tiwari, K.N.T., Yelmanda Reddy and
Shankar, M.A. 2007. Potassium supplying characteristics of twenty one soil profiles under divers rainfed production systems. J. Indian Soc. Soil Sci., 55(1): 14-22.

Ramanathan, K.M. and Krishanamoorthy, K.K. 1982. Potassium releasing power vis-a-vis potassium supplying power of soil. J. Indian Soc. Soil Sci., 30: 176179.

Raskar B.N. and Pharande A.L. 1997. Different forms of potassium and their distribution in some important soil series of Vertisols and Alfisols of Western Maharashtra. J. Potassium Res., 13: 21-30.

Srinivasrao, Ch., Subbarao, A. and Rupa, T.R. 2001. Need for inclusion of nonexchangeable potassium as a measure in soil test calibration and potassium recommendations. Fertiliser News.46: $31-38$.

\section{How to cite this article:}

Annapurna, M.V.V.I., B.S. Kadam, Nilam B. Kondvilkar and Surabhi, H.K. 2017. Potassium Supplying Capacity of Representative Soil Series of Sub-Montane Zone of Maharashtra, India. Int.J.Curr.Microbiol.App.Sci. 6(12): 2454-2458. doi: https://doi.org/10.20546/ijcmas.2017.612.284 